\title{
Laulutraditsioon ja kodupaik
}

Aivar J ürgenson

Kodupaika tajutakse mitmesuguste sümbolite või märkide kaudu. Kultuurikandjate poolt tähendusega varustatult kannavad need endas kodupaiga kontsentreeritud sisu. Mineviku sümbolites on maailm käega katsutav, konkreetne ja piiritletud. J ärgnevatel lehekülgedel vaadel dakse üht Siberi eestlastekultuuri kuuluvat nähtust, millel on olulinetähendus kodupaiga sümboolikas. See on laulutraditsioon.

Saja aasta eest võõrsile rännates võtsi d väljarändajad kaasa mitmed vana kodumaa kultuuri el emendid, sh seal lauldud laulud. Pole teada, kas ja kuivõrd laulsid väljarändajad laule väljarändamisest endast. Võiks ju oletada, et väljarändajad Iõid ja laulsid laule ees ootavast õnnemaast - kujund ol eksju iseenesest viisistamist-värsistamist väärt, kuid olemasolevad andmed seda ei kajasta.

Antropol oogilises võtmes on väljarännu puhul tegemist siirdumisega ühest staatusest teise. Rahvaluules on sellised si irdumised ajendanud iseseisvate kommeteja terveterahvaluuležanride väljakujunemist. Mõeldagu siinkohal näiteks rituaalsele itkutraditsioonile, mis on meie folklooris säilinud küll ainult setudel, kuid mõningail andmeil oli ilmselt varem tuntud mujalgi.

Setu aladel on laiemalt tuntud pulma- ja surnuitkud - mõlema sisuks on omaste kogukonnast eraldumine. Surnuitk kajastab vägivaldset eraldamist omaste kogukonnast - surm võtab kõi ki luba küsimata. Kuid vägival dse teema kajastub ka pulmaitkudes, oli ju paariminekul kuni 19. sajandi viimase veerandini sageli otsustav vanemate tahe (Tedre 2000: $230 \mathrm{jj}$ ).

Surnu- ja mõrsjaitkud on kohati käibel tänase päevani, hilisminevikust teame nekrutiitke. Sellel, miks eesti rahvatraditsioon ei tunne surnu-, mõrsja- ja nekrutiitkude kõrval näiteks väljarännuitke, ${ }^{1}$ võib olla mitmeid põhjusi. Agraarset talupojaühiskonda isel oomustas vähene mobi ilsus - Iõpl ik lahkumine omastest väljarännu käigus ol i liialt harv, et kujundada omaettetemaatilist žanri. Surnumatmine või paariminek on põlvkonnast põlvkonda ulatuvad kultuurilised universaalid - aeg, mida on kultuuril ol nud kasutada vastavate traditsioonide väljakujundamiseks, pole võrrel dav väljarändamise perioodiga. Nekrutiitkud, mis kajastavad pikkadeks aas- 
tateks kodumaalt lahkumist - liiati sunniviisilist ja seadusega sätestatut - , on reaktsioon vägival dselekodumaast eraldamisele, mille vastu ei saanud loomult paikne tal upoeg midagi ette võtta. Nekrutivõtmise regulaarsus ja sügav emotsionaalne reaktsioon kujundasidki omaette žanri - nekrutiitku.

Väljarändamisperioodi suhtelinelühiaegsus ja etapilisus - mõneaastased intensiivse väljarännu ajad vahel dusid väheaktiivsete perioodidega - ei loonud eeldusi väljarännuteemalise itkutraditsiooni kujunemisele. Pealegi olid nii surnu- kui ka pulma- ja nekrutiitkud väljarändamise ajaks elavast käibest kadunud, seega puudus ka vastav eeskuju.

Üksikud teated, kus kirjeldatakse väljarändajatekodumaalt lahkumist, ei paku palju võimalusi järelduste tegemiseks väljarändajatelaulurepertuaari osas. Mainida saab siinkohal näiteks teadet, kuidas Kaug-I tta si irdunud hi idl ased laul nud merele suunduva kaljase pardalt hüvastijätuks I samaa hiil gava pinnalta paistab kodu meil'kaunike, kallike(Saster 1987).

Võimalik, et tollasel E estimaal populaarsest isamaalaulude repertuaarist laenati sellises situatsioonis muidki palu - teema pakubju selleks või malusi. I samaalauludel, mis 19. sajandi teisel pool el Eestimaal üha populaarsust kogusid, võis olla väljarändajatele erilinetähendus. Häiritud territoriaalsus, oma turvaruumi kaotus oli soodsaks pinnaseks isamaalauludesügavale mõjule.

Kui vabatahtlik väljarändamine pole laulutraditsi ooni erilist jälge jätnud, si is ei saa seda öelda väljasaatmisteema kohta. Laulud, millel sisuks väljasaatmine, on olnud tuntud sajanditaguses Eestis, aga neid teatakse ka tänaste Siberi eestlaste seas.

Äraminek Tallinnasse,
siekurvastab mind.
J umalaga, truu neiu,
ei änam näema sind.
Sina olid minul armas,
sind armastasin ma
ja suovin, et vaksali
saadad sa mind viel.
J uba vilistas masin,
kolm korda Iõi kell.
Minu aeg on siin kasin,
ehk näeme viel teinekord. 
Aivar J ürgenson
Meid viiaks Siberisse
ja kaugemal vie,
kus vabrikud on valmis,
meid sunnitaksetüöl.
Nüid jumal aga jätan,
armas neiukene, sind.
Pika résu ette võtan,
Sahhaliini ruttan ma.
J äegeiaks, minu sõbrad,
sellekurbtusesies,
et täna viimist korda
viel seisan teieies.

(RKM, Mgn. Il 4364(11) - Anu Korb, Kadri Peebo 1995: 85-86)

Või teine, "Röövli laul":

Oh kuule, minu sõber, oh kuule,

mikspärast sa käruga käid?

Mikspärast sa kannad need rauad,

mikspärast sa katargu said?

Kord ol in mina röövlite pealik, meest kuuskümmend olid minu all, meieröövisimerikkaid ja vaeseid ja neiudelearmu ei and.

[---] Santarmid mind kinni siis võtsid

ja käru külgeneedisid mind.

Minu käed said selja taha seotud

ja katargu pool eläks tee.

Nüüd kuuled, mu sõber, nüüd kuuled,

mikspärast ma käruga käin,

mikspärast ma kannan need rauad,

mikspärast ma Siberi sain.

(RKM II 271, 26/7 - Anu Korb, Kadri Peebo 1995: 196)

Siit jõuameküsimusejuurde, milliseid laulelaulsid väljarändajad uuel kodumaal. Kui tänapäevanelaulurepertuaar Siberi eesti külades on tänu folk kloristide kogumistööle üldjuhul hästi dokumenteeritud, siis asundusteal gusaegadelauludekohta on andmed lünklikumad. Üheks olulisemaks allikaks tollase laulurepertuaari kohta on asunike kirjad. J enissei kubermangu Rõbinski külast 1899. aastal saadetud kirjas räägitakse sellest, et külas on tihti kuulda eestikeelset laulu, eral- 


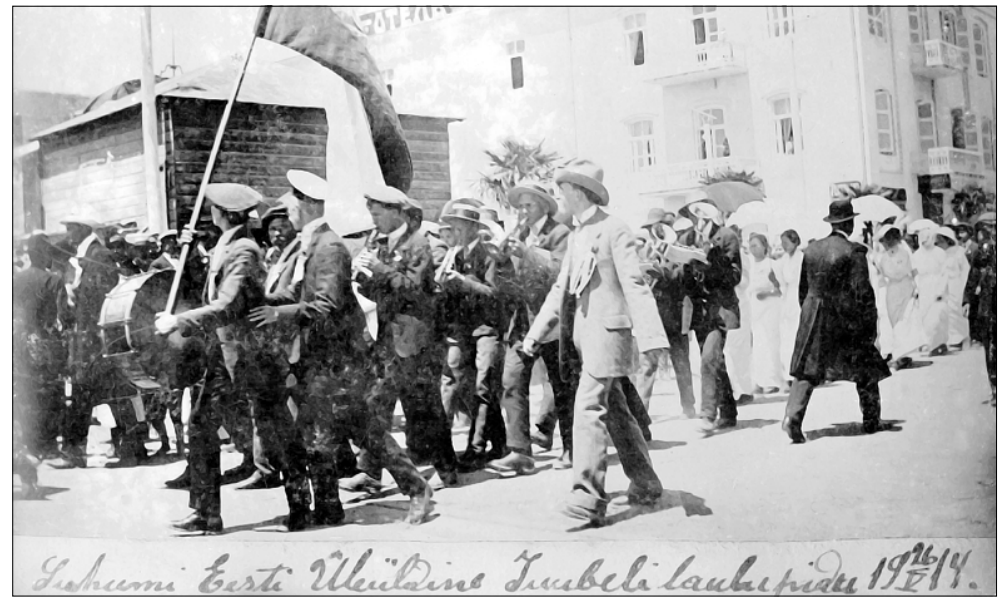

Venemaa eestlaste 1914. aasta laulupeo rongkäik Suhhumis Aloisi teatri ees (Marika Mikkor. Eestlased Musta mererannikul. Tartu 1998).

di nimetatakse ära laul "J ää J umalaga, I samaa" (Postimees 144 1899: 2). Tänase päevani lauldakse Siberi eesti külades laule, mis pärinevad 19. sajandi Iõpu ja 20. sajandi al guse Eestist. Sealnerepertuaar annab läbilõike tollasest lauluvarast, esindatud on erinevad žanrid ja teemad. See, et Rõbinski küla asunik oma kirjas just isamaateemalise laulu ära nimetab, on konteksti kaudu ju ka mõistetav - just need laulud omandasid võõras keskkonnas aktuaalsuse.

Nostal gilised vinjetid, mis esinevad asunike kodumaale saadetud kirjades, annavad tunnistust igatsusest kodumaa järele:

Elametasahiljukesi edasi ja vahete-vahel asub igatsus kodumaa ning sugurahva järelerinda ja si is sooviks seal viibida, kus Vanemuineaeg-ajalt oma iluheal esi kuulda laseb, mis iga tundliku inimesehingeülendavad (I lves 1903: 1074-1075).

See, et asunik Vanemuiselt küllap eelkõige isamaalaule kuulda soovis, ei ärata imestust, kuivõrd just need sümboliseerisid kõige selgemalt sidemeid kaugel asuva kodumaaga.

Asunike kirjadele kohati iseloomulik stiil, kus väljendati rahulolu asunduste majandusliku ol ukorra ning rahul ol ematust vaimse kultuuri seisukorra suhtes, puudutab ka laulutraditsiooni. Eesti koorilaulu ei kuuldu kusagilt, nenditakse ühes kirjas resigneerunult (Sakala 27 1910: 2). 
Kuigi mittenormatiivselaulurepertuaari osa ol i ja on Siberi eesti asundustes suurem, ei puudunud siiski ka koorilaul. Kui eesti asunduste aktivist Saamuel Sommer 1910. aastal Peterburis peetud I eesti asunduste hariduskoosolekul tegi ettepaneku korraldada asundustelaulupidu, kiitis koosol ek mõtte heaks ja otsustas laulupeo korraldada 1911. aastal Peterburis kui suurimas eestlaste keskuses väljaspool Eestimaad (Sakala 35 1910: 2).

Kuigi üritus plaanitud ajal teoks ei saanud, viidi asundustelaulupidu enne Esimest maailmasõda siiski läbi. See peeti Narvas 1912. aasta juunis. Põhirõhk oli isamaalauludel: repertuaari kuulusid sellised laulud nagu Karl August Hermanni "I samaa mälestus", Mart Saare "Mis mul meeldib", Christian Willibald Glucki "Rõõmu hääled", Friedrich Paciuse "Mu isamaa, mu õnn ja rõõm", Mihkel Lüdigi "Pisarad" jt tuntud isamaalised laulud (vt Esimese.. 1912). Osalisel kattus asunduste laulupeo repertuaar viimase Eesti üldlaulupeo (VII) omaga isamaalauludest näiteks Aleksander Kunileiu "Sind surmani", Miina Härma "Tule koju” (vt Tallinna III laulupidu laulud 1909). Samas oli asundustelaulupeo repertuaaris lisaks teistele isamaalistel elauludele silmatorkav hulk nostalgilise alatooniga nn võõrsil loleku laule: J ohannes Kappeli "Võõrsil”, Franz Schuberti “Kui kallist kodust läksin”.

E simese asunduste laulupeo mõju asunduste kultuurielule oli suur ning kuigi peagi alanud Esimene maailmasõda ja bolševike võimuhaaramine ei lasknud seda traditsiooniks kujuneda, peeti edaspidigi piirkondlikkelaulupidusid Venemaa eri paikades. Siberis oli üheks selliseks Tomski kubermangu Mariinski maakonna talurahva laulupidu 22.-23. juunil 1924 Vambola asunduses, kus lisaks nõukogulikule repertuaarile tulid ettekandele näiteks Minna Härma "Tule koju” ja Karl August Hermanni "Tervitus" (Maamägi 1980: 123-124).

Siberi eestlaste tänane laulurepertuaar hõlmab nii Eestist väljarännanutekaasa toodud, hilisematel kümnenditel Iaenudena omandatud kui ka kohapeal loodud laule.

E estist kaasa toodud lauludest on tänaste Siberi eestlaste seas üks populaarsemaid J ohannes Kappeli "Võõrsil”, mis, nagu nägime, kõlas ka asundustelaulupeol 1912. aastal Narvas.

Ka järgmine E estist kaasa toodud laul on levinud Siberi eestlaste seas ja siingi on teemaks eraldatus kodumaast:

Kauge üksi võera rahva hulgas, kauge üksi, kes mul tuttav on. 
Viibin üksi, süda suures mures, kadunud on kõik minu lust ja rõem.

Õnne ei ole mulle osaks antud, rõemu mul è olelubatud.

Kurvastus piab saama tühjaks kantud, valukarik täiest tühjendud [---].

(Korb 1999: 214-215)

Kuuludes eesti laulutraditsiooni, on võõrsilol eku laulude säilitamine Siberi eestlaste seas juba iseenesest mõistetav, sest küllap motiveerib ka el u võõrkeelses keskkonnas sellise sisuga laulude säilimist ning sagedast esitamist.

Siberi asunike laulurepertuaaris on olulisel kohal laulud, millel teemaks Siber. Siberit kujutatakse neis sageli sellele piirkonnale omistatud kanoonilisi tahke rõhutades - sageli esineb see hulkurite, varaste ja sunnitööliste maana, maana, mis on lage ja metsik.
Oh, Siber, sa, oh, Siber, sa,
sa kuul us vargapoi stemaa.
Ei seal kuulekukelaulu ega kana kaagutust.
Ei kuulekoera haukumist ega linnu laulmist. Ainult ahelatekõlinat ja tuulemühinat [---].
(Tõnurist 1967: 110)

Siberi teema seguneb lauludes teiste teemadega, nagu eraldatus kodumaast või väljasaatmine. Väga levinud on Siberi eestlastelaulurepertuaaris kodumaalgi populaarne "Pradjaaga laul":

Seal Siberis Baikali taga, kus põlised metsad ja maad.

Pradjaaga seal üksinda hulgub,

ära vandund oma isademaa [---].

(RKM II 272, 79/80 - Rosalie Ottesson)

Anu Korb, kes on uurinud Siberi eestlaste laulurepertuaari, täheldab näiteks Ülem-Suetuki puhul - aga sellele asundusele panid al use väljasaadetud - , et sealsed eestlased laulavad märksa rohkem vangilaule kui väljarännanute järglased. Ka on need lau- 
Iud Siberi eesti asunduste laulurepertuaaris olulisemal kohal kui Eestis (Korb 1998: 155). See, mida rõhutasime kodumaalaulude puhul, kehtib seega ka siin: konkreetne ajal ool ine taust on mõjutanud asundustes lauldavate lauludeval ikut ja kujundanud seal setele oludele spetsiifiliselaulurepertuaari.

Siber on väljasaatmise maa, ta on suur ja asub vanast kodumaast kaugel. Need on tüüpilised karakteristikud, mis leidnud kajastamist lauludes. Kuid Siberi-pildi juurde kuuluvad ka tahud, milles rõhutatakse maa suurt potentsiaali. "Laul Siberist" kujutab Siberit just selles valguses:

Oh, Siber, sa, oh, Siber, sa, sa kuulus viljarikas maa, oh, Siber, sa, oh, Siber, sa, sa kuulus viljakandja maa.

Seal siad liha annavad ja lambad villa kannavad. Oh, Siber, sa, oh, Siber, sa, sa kuulus viljakandja maa. Seal kanad munemunevad ja oinad liha annavad. Oh, Siber, sa, oh, Siber, sa, sa kuulus viljakandja maa...

(RKM II 271, 493/494 - RosalieOttesson)

Kodumaalauludena lisandusid Siberi eestlaste repertuaari Teise maailmasõja ajal ja järel uuemad eesti laulud, Siberi eestlaste kõnepruugis nn Eestimaa eestlaste laulud, mille tõid koduküladesse sõjast naasnud ja E esti Laskurkorpuses kodueestl astega koos võidelnud mehed - näiteks jõudis niiviisi Ülem-Bulankasse "Sauna taga tiigi ääres". Kõige sagedamini õpiti Eestimaa eestlaste laule aga Siberi eesti küladesse kosumisele saadetud eesti sõduritelt ja Eestist küüditatutelt. ${ }^{2}$

Seda, kuidas toimusid sellised kontaktid, kirjeldab üks ÜlemBulanka elanik (mees, sünd 1932):

Siin sõjaaegja pealesõja siin ol i palju neid... E estimaa œestlasi. Näe, Krasnaja Poljana, vot seal olid, koherohkem jagu... ühes ääres, ma tean, kohekõik olid nemad. J a nad käisid - meelasime, näe, siin üle jõe, seal tuba enam põle seal, minu selle... ema... emaema elas seal, vanaema - ja nad käisi d siin. Seal ka, venekoht ja... Nad ka nigu saivad teada, et eestlased siin ja... 
Saivad tuttavaks, iga pühapäe! Mina käisin nendega... laulsid eesti keeles. Neil olid ka... raamatud ühes. A meelasimekõrvu seal vanaemaga. Lähmeka lapsed, pl ikad - meil ol i kolmõdemina läksin kah, istume seal õue- suviaeg oli, soe seal väljas, pingid panivad, süia panivad, laulavad, ma ka nii kuulan seal .

Sama informant räägib ka, kuidas küüditatud laupäeviti-pühapäeviti Ülem-Bulankas käisid, Iõõtspill kaasas.

On täheldatud, et küüditatute laulutraditsioonis olid esikohal isamaa-ja nn kodulaulud (Hiiemäe2000: 131). Häiritud territoriaalsus, vägival dne lahtikistus kodumaast võimendasid küüditatutere pertuaaris kodumaalaulude väärtust. J ust küüditatute vahendusel jõudsid Siberi eestlasteni sel lised E estis populaarsed lood nagu "Kaugel, kaugel, kus on minu kodu", "Ma tahaksin kodus olla", "Läänemere lained". Oluline on neis lauludes geograafiline, looduskeskkonda puudutav moment. Mitmete laulude sõnad kohandati uues paigas vastavalt kohalikele oludele ümber. Siberi eestlaste seas Eestimaa eestlaste lauluna tuntud "Kaugel-kaugel, kus on minu kodu" Iõpeb Virukülas nii:

\section{Ülelageda Siberi kõlab kurb ja igatsev eestlastelaul.}

Ülem-Bulanka eestlased mäletavad, et sellistesõnadega - Siberi asemel esineb neil laulus Venemaa - laulsid seda esimesena küüditatud.

Huvitav näide on algselt saksa lauluna sündinud "Läänemere lained", mille al gkuju peaks pärinema 1939. aastal pimedana surnud pommerlanna Martha Müller-Grählerti loomingust ja ilmus esimest korda trükis 1908. aastal. Tõl getena levis laul kiiresti naabermaadesse (Rebane 2000: 208; Greverus 1965: 12-13). Tõl gete kõrval levisid ka töötlused, nii saksa kui teistes keeltes. Algsed sõnad Wo dieOstseewellen... asendati Venemaaleja Ukrainasse välja rännanud sakslaste repertuaaris kohisevate mändidega või uue kodupaiga jõe lainetega: Wo die Kiefern raunen leis ihr heimlich Lied, Wo dieDesna Wellen... (Greverus 1965: 13). Kaukaasias Sulevi külas lindistasin eestikeelse "Läänemere lainete" töötluse, milles sümbool sete kodumaa maastikena nimetatakse Kaukaasia loodusobjekteja pinnavorme. Sellised töötlused näitavad, kuivõrd tugevalt isel oomustavad kodumaad spetsiifilised kodumaamaastikud ja kuidas seda maastikulisust rahva seas kodumaa sümbol iseeringus aktsepteeritakse. 
I na-Maria Greverus on töötluste massilist levikut pidanud koduigatsuse leevendamise vahendiks olukorras, kus väljarändajad tajuvad uues keskkonnas kohanemisraskusi. Laulutöötluste kasutamises näeb ta sümbool set tagasi pöördumist paremasse keskkonda (Greverus 1965: 12-13). Tegelikult levisid populaarsed kodumaalaulud ja nende töötlused ka mitmenda põlvkonna asunikeseas, s.t olukorras, kus inimeste territoriaalsus ei ole häiritud.

Palju lauldakse Siberi eesti asundustes ka venelaule. Need ilmusid Iaulurepertuaari juba 19. sajandil. Ühes 1897. aastal Eestisse jõudnud Omi asunduse elu kirjelduses mainitakse, et puuduliku keel eoskuse tõttu on venekeelsete laulude hääldamine väga vale. Kirjutise autor räägib sel lest, kuidas tüdrukud on venel astelt üle võtnud kombe pühapäeviti salgakaupa külatänaval jalutada ja karjuda, vahel kestvat selline laulmine öö läbi, nii et kõikide öörahu on häiritud (G.E.L. 1897: 844). Niisiis omandasid laulurepertuaar kui muusikaline käitumine juba 19. sajandi Iõpul vene jooni. Aja jooksul on tendents süvenenud, lauldakse vene laule, levib kooslaulmine, kusjuures hääletämber või b olla venepäraselt kime, esitus venitav ja aeglane, seda kohati ka traditsiooniliste eesti laulude puhul.

Sada aastat tagasi kirjutas asunik halvustavalt tüdrukutest, kel kombeks külatänaval jalutada ja valjusti laulda. Sellist suhtumist kohtab tänapäeval gi. Uutelaulužanride peal etulek ning repertuaari muutumine toob kaasa põl vkondade konflikti. Oma noorusaega kuuluvat peetakse paremaks ja õigemaks, tänapäevaseid käitumisviise kritiseeritakse. N ostal gilised meel eol ud haakuvad kaasaja kriitikaga:

Küll ol i siis [s.t varem, jutustaja noorpõlves] si in seda mõtsiku mängimist, või dujooksmist, värvimängi mi st ja si is ta... oi-oi oi, küll oli lõbus elu! A nüüd... N eed noored jau, jau... No mis sa kurrat vingud, sa laula kui inimene! [---] Nad è pea viitki või nad ei oska... viitsigi või mis nad on, ma ei tea.

A. J .: Ikka eesti laulud olid vanasti ainult?

Kõik eesti laulud! Ei... kis seeennevenelaulusi laulis!? (naine, sünd 1927, Ülem-Suetuk).

Siberi eestlaste laulurepertuaaris esineb eesti-vene segakeelseid laule. $^{3}$

Annuška, minu õnnelind, ah, satšem tõi plaatšiš? 
Sulleaga tuksub minu rind, armastad, tak hootšiš.

(RKM, Mgn. II 4371 (10, 12) - Anu Korb, Kadri Peebo1995: 112)

Kui laupa õhtu lauluga

läen oma pruuti vaatama.

Ei, või poljaa,

krasnõi kavaljeer

sa bõstra na kanjah.

Ta u ta.

Ei, või poljaa,

seljoonõjepoljaa,

krasnõi kavaljeri

sa bõstra na kanjah.

(RKM, Mgn. II 4372 (1) - Anu Korb, Kadri Peebo 1995: 113)

Segakeel setelaulude puhul Siberi eestlasterepertuaaris ei saa teha automaatset järel dust kohapeal sete vene mõjude kohta. On tõenäoline, et selliseid laule tekkis ka Siberis, kuid tuntud ol i seelaululiik juba Eestis enne väljarändamist. Enamgi veel - näiteks laulu 'Vihma sajab kak s vedraa", mis mitmetes Siberi eesti külades väga populaarne, tõid sinna Eestist küüditatud (Anu Korbi suuline teade). Ennatlik järeldus, et mitmekeelsed laulud Siberi eestlaste repertuaaris on tekkinud kohapeal, pole seega õige. Samas on mitmekeelsete laulude repertuaar eriti rikkalik näiteks Rõškovo külas, mille eripäraks on see, et seal elab külg külje kõrval palju erinevaid rahvusi. Rõškovos lauldakseka saksa-vene segakeel seid laule(Anu Korbi suulineteade).

Sageli on vene laulud tõlgitud eesti keelde ja inkorporeeritud täielikult käibivasse laulurepertuaari. Omaaegsed venelaulud või pillilood saavad niivõrd omaseks, et enam ei tajuta nende kuulumist võõrasse kultuurialasse. Siin võiks nimetada eespool tsiteeritud "Pradjaaga Iaulu". E estikeel sete sõnadega laulduna on laul sulandunud kohalikku folkloori.

Eesti lauludest ei osata enam eristada traditsioonilisi venelugusid. J uba mitukümmend aastat E estis Harkus el av Si beri eestlane laul is si in ühel koosviibimisel vene rahvalaulu, pi dades seda enesestmõistetavalt eesti lauluks. E estipäraseks peetakse näiteks Ülem-Suetuki külas kahehäälset laulmist ja vastandatakse seda soomlaste neljahäälsele laulmisele. 


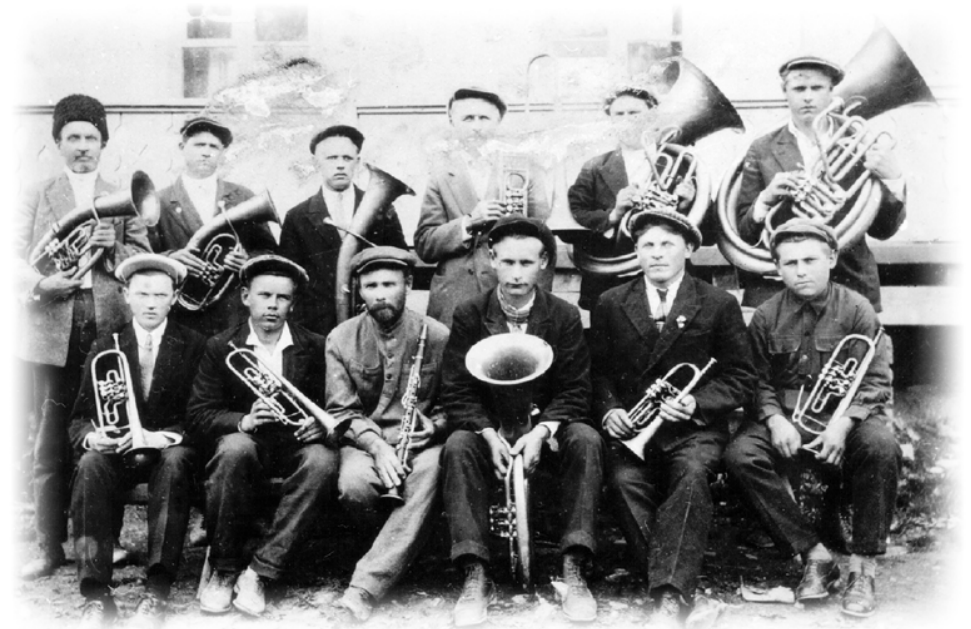

Alam-Linda muusikakoor 1930. aastatel (Marika Mikkor. Eestlased Musta mererannikul. Tartu 1998).

Siit jõuame tõdemuseni, et Siberi eestlaste lauluvara on suuresti rahvusvaheline. Sellel on ka üldisem taust: naabritena elavaterahvusrühmade laulurepertuaar kattub osaliselt. Palju on Iaule, mida laulavad nii eestlased, lätlased kui ka venelased, igaüks omas keeles. Üldisemat laadi tähelepanek, mis ei puuduta üksnes laulutraditsiooni, ongi see, et kultuurinähtused eksisteerivad keeleülestena, segaasustuse puhul minetab keel aja jooksul oma kultuurinähtuse eksistentsi võimal dava funktsiooni. Samas võib keel anda kultuurinähtusele uue dimensiooni. Venelaul, mida lauldakse eesti keel es ja peetakse eesti lauluks, kuulub kooslusse, mille elemendid kujutavad endast identiteedi sümboleid.

Suurt rolli identiteedi kandjana mängis näiteks Tsvetnopolje eestlastelauluansambel, kohalike kõnepruugis eesti foljklor. Eestvedajana tegutses küla klubijuhataja Linda Tsirk. Kuigi vahel kaasati esinema ka muudest rahvustest külaelanikke - nendele kirjutati eestikeelsed laulud üles vene tähtedega - , koosnes ansambel valdavalt eestlastest. E sineti erinevates koosseisudes, näiteks tegutsesid paralleelselt Linda Tsirgu vokaalinstrumentaalne perekonnaansambel ja õdede trio. Nii suuremate kui väiksemate koosseisudena esineti regionaalsetel folklooriülevaatustel, pidudel, spordi- 
võistlustel. Peamiselt esitati laulud eesti keeles, kusjuures arvukalt oli repertuaaris esindatud uuemaid autorilaule. Mitmed lood olid üle võetud ka näiteks eesti Lääne-pagulasterepertuaarist. Nõukogudevastaste laulude eestikeelne esitamine Siberi venekeel sele publikule oli kahtlemata ohutum kui nende avalik laulmine Eestis.

Tsvetnopolje eestlaste lauluansambliga seoses tuleb rõhutada selle rolli kohaliku eesti kogukonna konsolideerija ning rahvustunde säilitajana.

Ülem-Suetuki külas tegutseb juba aastast 1901 pasunakoor, mida praegu juhatab külavanem Ärni Lell. Esinetakse samuti regionaalsetel ülevaatustel, orkestrit kutsutakse mängima teistegi külade pidudele, käidud on mängimas Esto päevadel Rootsis. Nii nagu ütles üks naabruses asuva eesti küla Ülem-Bulanka endine elanik (naine, sünd 1958), hoiab Ülem-Suetuki intelligentsust ülal puhkpilliorkester.

Laule on lauldud ning pilli mängitud erinevates olukordades. Pühade, nagu näiteks jaanipäeva, tähistamisejuurde on alati kuulunud ka musitseerimine. Kuid lauldud ja pilli mängitud on ka kiigel, tänaval või lihtsalt üksteise juurde kokku tulles.

No vaat, noored olivad. Meil olivad niuksed suured kiiged tehtud. Vat üks kiige oli seal Kundeluku uulitsas oli. Suur ki ige- no sinna kole palju rahvast istus peal. Nad olid... kolmel real niimoodi olivad: keskpaigas olid lauad ja siis olid niuksed aisad. Suur seeol i... aampalk ol i, suure posti deotsas olivad. Siis kiikusivad. No vot siis noored istusid seal peal, si is nad laulsivad ja kiikusivad seal. J a üks ki igeol i näesiin just selle Mannu vasta tuleb. Vaat kus seevana pood meil on, seal oli... Kus nad puid saagisivad... Vot sial ol i meil üks kiige Vaat niimoodi siis... A klubisi meil ei old. A kui korjasivad kokku nigu... tahtsid seal tantsi da - talvel on ju külm väljas no kelle suured toad on... No ütlesid täna õhta, et: "Laske meid nigu tulla." - No siis ikka, et kui oli meil nigu suurem ruum, siis tantsisivad, mängisivad pilli (naine, sünd 1926, Ülem-Bulanka).

J a vaata mis veel meil olid... No õhtati no... Vahest olivad meil, istusimeväravates. Kui olivad noored, noored seal ved tantsisi vad värava esimeses, seal tantsisivad. Vanad istusivad, seal pingid ol ivad. Vaat siis laulsivad. I stusivad õhtati väljas. Vahest kaua aega istusivad! Enne olid Iõbusad inimesed, a 
mis nüid... Nüid ei ole. Istusivad kohe, vanad istusid väljas. Kevadeaeg, esteks, vaata kui juba lumi läks ära, si is meil ol i üks... seal oli suur sild meil seal Kundeluku mäe all, suur sild. A seal ülesilla, nigu siiapooleäärde on, suur plats oli. Niukeilus lai. Siis ol id seal, mõni seal vana ol i ja siis noored kõik olivad, ringi mängisid. A nüüd seal enam ringi ei mängivad. A meil esteks mängisivad ringi. Ringilaulusi laulsivad ja tantsisivad. Kui pilli ei old, mängisivad ringi ja tantsisivad. J a si is juba tuli meil kalkoosi aeg, vaat inimesed nigu... on juba... olid sellega nigu ära õppind, läksivad metsa - siis vähelaulsivad - no kui õhtaks hakkasivad kodu tulema, si is nigu mõned pulmalised tulivad kohe. Siis nad nii kõvasti laulsid. No sel lepärast, et brigadad ol ivad. Teinebrigada läks teinepoole, esimene brigada läks teinepoole - no siis... igas brigadas seal - hobustega heinamaalt tulivad - siiluse aeg kõige rohkem, kui tegime siilust - si is koledasti laulsi vad. Tulivad kodu siiluselt, käisivad Iõunal kodu, tulivad, puhkasivad, läksid jälletagasi - vat siis laulsivad (naine, sünd 1926, Ülem-Bulanka).

Eestikeelse laulurepertuaari esitamisel on Siberi eestlaskonnas eestluse säilitamise ja rõhutamise funktsioon. Laulutraditsioon tõmbab piiri omade ja võõraste vahele keele alusel. Tehakse vahet kuigi, nagu eelnevalt nägime, omal moel - eesti ja vene lauludel. Vanem põlvkond tähtsustab eesti lauludeesitamist ja mõistab noori hukka venekeelserepertuaari pärast. Eesti laulude hulka kuuluvad ühelt poolt Siberi eestlaste laulud, teiselt poolt Eestimaa eestlastelaulud, kuid mõlemad kihistused on eestikeel sena siiski omad. Erinevates Siberi eesti külades lauldakse ühtesid ja samu laule, kuigi on ka varieerumisi.

Nüüd peatumegi neil varieerumistel. Kui ühelt poolt eristatakse eesti ja vene laule, siis samas tehakse vahet ka erinevate eesti küladelauludel. On Suetuki laulud ja Pulani Iaulud, on Lilliküla ja Pardinova laulud. Külati on erinevusi repertuaaris ja esitusviisis, mis toob välja laulutraditsiooni lokaalse aspekti. Üks Ülem-Bulanka elanik (naine, sünd 1926) räägib oma küla ja Ülem-Suetuki laulumaneeride erinevusest: J a meienigu venitame, aga nemad è. $\mathrm{Ne}$ mad nigu ütlevad kohevälja ja viis on teineneil.

Konkreetse küla lauluks nimetatakse kas konkreetses külas loodud laulu või laulu, mille sõnad on pühendatud konkreetsele 
külale, enamasti aga piisab sellest, et seda või teist laulu lihtsalt lauldakse konkreetses külas.

Estonka küla elaniku esitatud laul naaberkülast Lillikülast algas sõnadega:

Sõitsin, sõitsin Lillekülla ennepäiva minekut.

Trai-rai, rai-rai, ral-lal-laa, ennepäiva minekut.

(Korb 1999: 224)

Laulu kompositsioon viitab sellele, et tegemist on Eestist pärit lauluga, mis on kohandatud uue keskkonnaga.

Või Lillikülast pärit naine, kes laulab Pardinovast:

Pardinova külas pallu poisse,

kõik on eesti poisid.

Sibi-libi-liuhka, labidaga tuhka

eesti poiste keele peale.

Eesti poisid, ärgeminge

tuisu ajal välja.

Tuisk teid matab, tuisk teid katab,

kos teiial jääte

Sibi-libi-liuhka, labidaga tuhka

Pardinova poistekedepääle.

(Korb 1999: 236)

Mihhailovka küla mees laulis J urjevi külast:

J ürjevi külas Tedrekraavis,

kos oll Miilil kusi kraanis.

Ta ronis suurdepajju

ja kussi Vähja kaivu ja.

(Korb 1999: 245)

Estonka külas lauldakse ka peamisest kohalikust kaubanduskeskusest:

Üts vana ja üts vaene mees

kes el as talu sauna sees.

[---] Ta tegi kulpe, lusikid

ja treias visper karikid. 
Aivar J ürgenson

[---] Ta võttis kauba õlale ja läks si is Tara turule[---].

(Korb 1999: 229)

Külades on ol nud ka oma laulul oojad, näiteks Ülem-Bulanka kuulus külalaulik J aan Mägi, kes on paljude lugude autor. Ajutise Valitsuse kukutamisejärel läksid käibelt senised rahatähed, mida anti nüüd lastele mängimiseks või kleebiti seintele. Kui kukutati Koltšak, toimiti samamoodi tema valitsuse rahatähtedega. Süžee andis J aan Mägi laulus edasi järgmiselt:

Bulani külas eesti rahvas, kõik nad joovad viina vahvast.

Simvai ruudi rallala, simvai, simvai rallala.

[---] Palju raha kokku aeti, lastel mänguasjaks anti.

Simvai ruudi rallala, simvai, simvai rallala.

Raha peal on keisri kuju, seinaleneid pildiks panti.

Simvai ruudi rallala, simvai, simvai rallala...

(RKM II 288, 211/212 - RosalieOttesson)

Siberi eestlaste repertuaaris on siiski vähe puhtalt omal oomingulisi laule. Ka külalaulude puhul on enamasti tegemist E estist pärit laulutüüpidega, mis on Siberis kohandatud seal setele ol udele vastavaks. Paikkonna eripära, nii geograafiline kui ka sotsiaalnekeskkond, on vorminud laule, mis väljarändajad sajandi eest Eestist kaasa tõid, kohapealsetelt rahvastelt laenasid või ka hilisematel kümnenditel Eestist õppisid.

Oma koduküla või Siber tervikuna on need vormid, millesse valati ja valatakse erinevaid Siberi eestlastelaulurepertuaari kuuluvaid lugusid. I sel oomulik on ka nihe, mille on teinud läbi kodumaalaulud. Algselt Eestist tooduna sümboliseerisid nad sidet Eestiga. J ärgnevatele põlvkondadel e hakkasid samad laulud tähendama sidet kodupaigaga Siberis. Vajaduse korral kohandati ka laulude sõnad kohalikel eoludel e vastavaks. Aja jooksul on kodupaiga sümbolina funktsioneerinud laulud muutnud konkreetses keskkonnas oma esialgset tähendusnüanssi - vana kodumaa tähistajatest on saanud uue territoriaalse rühma identifikaatorid. 


\section{Kommentaarid}

${ }^{1}$ Väljarändajate itkusid on teada Kreekast, Ungarist, I irimaalt. Seejuures on sälitatud traditsionaalne itkustiil (Greverus 1972: 178-179).

${ }^{2}$ Seda tõika kinnitab lisaks Siberi eestlaste endi jutule fakt, et näiteks Kaug-I da eesti külade elanikel pole Eestist küüditatutega otseseid kontakte olnud ja nad ei tea ka seda laulukihistust.

${ }^{3}$ I.-M. Greverus nimetab mitmekeel seid laule kaotatud identifikatsiooniruumi sümboliks (Greverus 1972: 62).

\section{Kasutatud kirjandus}

Esimeseasundustelaulupidu laulud Narvas 23. ja 24. juunil 1912. a. Tallinn. G.E.L. 1897 (= Georg Eduard Luiga). Omi kaldalt I-IV. Olevik 33 (19. august), Ik 740-741; 37 (16. september), Ik 821-822; 38 (23. september), Ik 844; 40 (7. oktoober), Ik 891.

Greverus, Ina-Maria 1965. Heimweh und Tradition. Schweizerisches Archiv für Volkskunde 61, Basel, Ik 1-31.

Greverus, Ina-Maria 1972. Der territoriale Mensch. Ein literaturanthropol ogischer Versuch zum Hei matphänomen. Frankfurt am Main.

Hiiemäe, Mall 2000. Küüditatuna Siberis. Aivar J ürgenson (koost). Eestlane ja tema maa. Tallinn, Ik 122-136.

Ilves, K. 1903. Kiri Siberist. Olevik 45 (6. november), Ik 1074-1075.

Korb, Anu \& Peebo, Kadri (koost) 1995. Siin Siberi maa peal kasvanud. Eesti asundused I. Tartu.

Korb, Anu 1998. Siberi eestlaste lauluvara. Astrid Tuisk (toim). Eesti kultuur võõrsi l. Loode-Venemaa ja Si beri asundused. Tartu, Ik 143-157.

Korb, Anu (koost) 1999. Taaru-tagused ja stepiasukad. Eesti asundused IV. Tartu.

Maamägi, Viktor 1980. U ut elu ehitamas. Eesti vähemusrahvus NSV Liidus (1918-1940). Tallinn.

Rebane, Hilve 2000. Kodupaik ja kodumaa J uhan J aigi loomingus. Aivar J ürgenson (koost). Eestlane ja tema maa. Tallinn, Ik 207-214.

Saster, Alja 1987. Eestlasted uol ust Kaug-I das (Vladivostok). KV 551: 111-255.

Tallinna III Iaulupidu laulud 1909. Tallinn.

Tedre, Ülo 2000. Itku relikte eesti pulmakombestikus. Kristi Salve \& Mare Kõiva \& ÜloTedre (toim). Tagasi pöördumatus. Sõnad ja hääl. Tartu, Ik 228-237.

Tõnurist, Igor 1967. Etnograafilisi märkmeid Minussinski eestlastest ja lätlastest (Ida-Siber). KV 195: 108-166. 